\title{
KORELASI KOMPETENSI PEDAGOGIK GURU PAI DENGAN MOTIVASI BELAJAR PESERTA DIDIK DI SEKOLAH INKLUSI
}

\author{
Suliwati \\ Fakultas Tarbiyah dan Ilmu Keguruan. IAIN Salatiga \\ suliwati456@gmail.com
}

\begin{abstract}
Abstrak
Penelitian ini bertujuan untuk mengetahui apakah terdapat korelasi antara kompetensi pedagogik guru PAI dengan motivasi belajar peserta didik dalam mata pelajaran PAI pada sekolah inklusi di SMP IT Nidaul Hikmah Kota Salatiga pada tahun ajaran 2018/2019. Subjek dalam penelitian ini adalah peserta didik kelas VII B dan VIII B yang berjumlah 62 orang termasuk peserta didik berkebutuhan khusus tunadaksa dan kesulitan belajar (slow learner). Jenis penelitian ini adalah penelitian kuantitatif pendekatan korelasional. Metode yang digunakan untuk mendapatkan data atau informasi menggunakan angket/lembar kuesioner. Analisis yang digunakan dalam penelitian ini adalah menggunakan analisis deskriptif dan analisis uji hipotesis korelasi product moment yang dibantu dengan program aplikasi SPSS versi 25.00. Hasil penelitian ini diperoleh bahwa kompetensi pedagogik guru PAI yang masuk kategori sangat rendah sebesar 3,2\%, kategori rendah sebesar 27,9\%, kategori sedang sebesar 48,4\% dan kategori tinggi sebesar 20,9\%. Motivasi belajar peserta didik dalam mata pelajaran PAI yang masuk kategori sangat rendah sebesar 27,4\%, kategori rendah sebesar 27,4\%, kategori sedang sebesar 33,9\% dan kategori tinggi sebesar 11,3\%. Hubungan kompetensi pedagogik guru PAI dengan motivasi belajar dalam mata pelajaran PAI berdasarkan perhitungan korelasi menyatakan bahwa hipotesis nol (Ho) ditolak dan hipotesis alternatif (Ha) diterima dengan nilai $r_{x y}>r$ tabel sebesar 0,495 $>$ 0,244 . Menunjukan bahwa hubungan kompetensi pedagogik guru PAI dengan motivasi belajar peserta didik dalam mata pelajaran PAI mempunyai korelasi positif yang sedang dan signifikan.
\end{abstract}

Kata Kunci: Kompetensi Pedagogik Guru, Motivasi Belajar, Pendidikan Agama Islam, Pendidikan Inklusi

\begin{abstract}
This study aims to determine whether there is a correlation between the pedagogical competence of Islamic Education Teachers and the learning motivation of students in Islamic Education subjects in inclusive schools at SMP IT Nidaul Hikmah, Salatiga in academic year 2018/2019. The subjects in this study were 62 students of class VII B and VIII B including students with special needs with disabilities and learning difficulties (slow learner). This approach of research is quantitative correlation. The method used to obtain data or information by using a questionnaire or questionnaire sheet. The analysis used in this research is using descriptive analysis and the product moment correlation hypothesis testing which assisted by the application program SPSS version 25.00. The results of this study showed that the pedagogical competence of Islamic Education teachers in the very low category was $3.2 \%$, the low category was $27.9 \%$, the moderate category was $48.4 \%$ and the high category was $20.9 \%$. The learning motivation of students in the Islamic Education subject in the very low category was $27.4 \%$, the low category was $27.4 \%$, the moderate category was $33.9 \%$ and the high category was $11.3 \%$. The correlation between Islamic Education teacher pedagogical
\end{abstract}


competence and learning motivation in the Islamic Education subjects based on the calculation of the correlation stated that the null hypothesis (Ho) was rejected and the alternative hypothesis (Ha) was accepted with the value of $r_{x y}>r$ table with $0.495>$ 0.244. Indicated that the correlation between the Islamic Education teacher pedagogical competence and students learning motivation in Islamic Education subjects has a positive moderate category and significant correlation.

Keywords: Teacher Pedagogical Competence, Learning Motivation, Islamic Education, Inclusive Education

\section{PENDAHULUAN}

Indonesia memiliki masyarakat dengan latar belakang budaya, agama dan adat-istiadat berbeda. Berdasarkan hal tersebut maka setiap individu harus mempunyai sikap yang toleran dan anti-diskriminasi. Perbedaan anak dari segi fisik, komunikasi, perilaku dan kemampuan menjadi sangat rentan dengan perlakuan diskriminasi. Anak berkebutuhan khusus menjadi diperlakukan tidak adil menurut sistem pendidikan. Sarana untuk menimba ilmu terbatas pada sekolah luar biasa yang tidak semuanya dapat diberikan fasilitas dengan baik. Pendidikan merupakan bagian dari hak asasi manusia dan hak setiap warga negara yang usaha pemenuhannya harus direncanakan, dijalankan dan dievaluasi (Indriawati, 2013). Setiap aspek pendidikan sudah selayaknya mampu menerapkan nilai-nilai dari hak asasi manusia. Contoh dalam pengaplikasiannya adalah sikap anti diskriminasi dalam berbagai aspek guna mewujudkan dunia pendidikan yang harmonis. Menurut hasil dari Survei Sosial-Ekonomi Nasional 2018 UNESCO dalam laporannya mengemukakan terdapat sepertiga dari total 75 juta anak yang tidak dapat memperoleh haknya dalam mengenyam pendidikan adalah para penyandang disabilitas. Berdasarkan data Dapodik tahun 2018 yang dilansir oleh kompas menyatakan bahwa sebaran siswa penyandang disabilitas di Indonesia terdapat 993.000, sebanyak 91.000 anak berkebutuhan khusus berada di sekolah inklusi. Anak berkebutuhan khusus harus mendapatkan pendidikan yang layak untuk mengembangkan potensi dan bakatnya bukan hanya melalui sekolah luar biasa. Pendidikan inklusif merupakan konsep pendidikan yang tidak membeda-bedakan latar belakang kehidupan anak karena keterbatasan fisik maupun mental (Ulva dan Maria: 2020). Education at all merupakan suatu pendidikan yang dipandang ideal sebagai inti dari pencapaaian tujuan pendidikan inklusi di negara berkembang (Armstrong, dkk: 2011). Pendidikan inklusi memberikan kesamaan kesempatan kepada semua orang untuk berpartisipasi penuh dalam semua kegiatan belajar atas dasar kesetaraan dengan mengakomodasi kebutuhan khusus (Tarsidi, 2012). Berdasarkan hal tersebut maka akan tertanam sikap menghargai orang lain, mampu mengembangkan karakter Islami dan tidak saling membedakan dalam melihat kekurangan/keterbatasan orang lain. Sesuai dengan firman Allah Swt. 


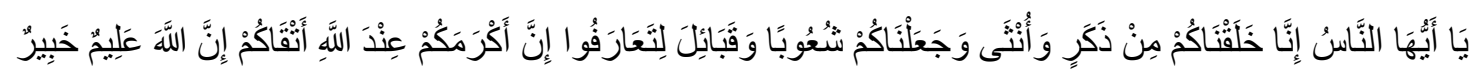
Terjemah Al-Qur'an: "Hai manusia, sesungguhnya Kami menciptakan kamu dari seorang laki-laki dan seorang perempuan dan menjadikan kamu berbangsa-bangsa dan bersuku-suku supaya kamu saling kenal-mengenal. Sesungguhnya orang yang paling mulia diantara kamu disisi Allah ialah orang yang paling takwa diantara kamu. Sesungguhnya Allah Maha Mengetahui lagi Maha Mengenal." (Q.S Al-Hujurat:13)

SMP IT Nidaul Hikmah adalah sekolah Islam terpadu di Kota Salatiga yang mempunyai misi salah satunya memberikan pelayanan pendidikan pada semua kalangan dengan pendidikan inklusi. Guru di SMP IT Nidaul Hikmah menyadari bahwasanya setiap peserta didik mempunyai karakteristik yang beragam mulai dari anak reguler atau anak yang berkebutuhan khusus terutama dalam penyampaian materi. Salah satu faktor internal dalam meningkatkan kualitas pendidikan adalah kompetensi guru. Profesionalisme seorang guru dapat dinilai dari kompetensi yang dimiliki. Kompetensi yang wajib dimiliki adalah pedagogik, sosial, kepribadian dan profesional. Kompetensi pedagogik berkaitan dengan seni mengajar yang dilakukan seorang guru. Kompetensi pedagogik guru di sekolah inklusi pasti akan berbeda apabila dibandingkan dengan sekolah reguler pada umumnya. Kemampuan seorang guru dalam mengelola pembelajaran di sekolah inklusi sangat dibutuhkan guna mewujudkan keberhasilan pendidikan. Peningkatan pengetahuan dan ketrampilan merupakan salah satu cara memberdayakan guru dalam melayani kebutuhan siswa disabilitas (AlZyoudi: 2006). Kompetensi pedagogik dalam penelitian ini adalah pandangan peserta didik tentang kemampuan guru Pendidikan Agama Islam yang berkaitan dengan seni mengajar dalam memberikan pemahaman menyeluruh terhadap pembelajaran dan karakteristik subjek pembelajar sehingga mampu mencetak peserta didik yang dapat mengembangkan bakat, minat dan potensi diri.

Menurut Sardirman (2010) guru harus berusaha dan memberikan motivasi agar tejadi proses interaksi yang kondusif. Motivasi belajar sangat berkaitan dengan hasil pembelajaran. Setiap individu akan bergerak jika mendapatkan dorongan. Mencapai suatu tujuan maka dibutuhkan motivasi yang kuat. Motivasi belajar yang tinggi akan berpengaruh terhadap hasil belajar yang bagus begitu juga sebaliknya. Pendidikan Agama Islam sebagai basis pendidikan karakter bangsa dan agama harus memiliki output yang baik sesuai dengan tolak ukur yang ada. Nilai-nilai keagamaan harus dapat diaplikasikan dengan benar pada diri peserta didik, sehingga akan mewujudkan hasil belajar yang sesuai baik dalam aspek pengetahuan (kognitif), sikap (afektif) dan ketrampilan (psikomotorik). Motivasi belajar yang rendah berhubungan dengan hasil belajar peserta didik yang menurun. Motivasi belajar dalam mata pelajaran pendidikan agama Islam dalam penelitian ini adalah dorongan untuk menuju perubahan yang baik dalam mencapai cita-cita yang berkaitan dengan pengetahuan yang diperoleh melalui usaha mengarahkan dan mendidik peserta 
didik agar mengetahui, memahami dan mempraktikan ajaran Islam. Motivasi belajar perlu dibangun melalui lingkungan eksternal melalui kompetensi guru. Peserta didik yang lemah dalam motivasi belajarnya dapat disebabkan dari cara guru mengajar sehingga akan terjadi kebosanan dan rasa jenuh. Ada berbagai macam karakteristik dan kebutuhan peserta didik terutama dalam upaya menangani anak reguler dan anak berkebutuhan khusus yang perlu dibimbing dan diberikan motivasi belajar. Sebagai wujud perhatian terhadap proses pembelajaran, guru di SMP IT Nidaul Hikmah harus menyadari bahwasanya setiap peserta didik mempunyai karakteristik yang beragam mulai dari anak reguler atau anak yang berkebutuhan khusus terutama dalam penyampaian materi. Kondisi fisik dan psikis peserta didik beragam mulai dari yang semangat, kurang semangat atau bahkan bosan dalam menerima materi pelajaran. Permasalahan tersebut yang menjadi latar belakang pentingnya motivasi belajar untuk mencapai tujuan belajar yang sesuai dengan target.

Berdasarkan suatu penelitian menyatakan bahwa terdapat pengaruh signifikan secara simultan antara kompetensi pedagogik dan kompetensi profesional guru terhadap motivasi belajar siswa di MAN 5 Jombang (Wahyuningsih: 2010). Penelitian lain menyatakan bahwa terdapat hubungan yang positif dan signifikan antara kompetensi pedagogik dan profesional terhadap motivasi belajar siswa (Santika, dkk: 2013). Menurut data dari berbagai hasil penelitian dan gambar latar belakang di atas maka menunjukkan bahwa terdapat hubungan antara kompetensi pedagogik dengan motivasi belajar, hal tersebut yang mendorong peneliti untuk melakukan penelitian dengan tema ini menggunakan sampel di SMP IT Nidaul Hikmah berkaitan dengan penyelenggaraan pendidikan inklusi.

\section{METODE}

Jenis penelitian ini adalah penelitian kuantitatif pendekatan korelasional. Jenis penelitian yang bertujuan untuk mengetahui ada tidaknya hubungan antara dua atau beberapa variabel yang dinotasikan dengan angka kuantitatif (Arikunto: 2016). Variabel bebas dalam penelitian ini adalah kompetensi pedagogik guru yang meliputi aspek dalam penguasaan karakteristik peserta didik, teori/ prinsip belajar yang mendidik, pengembangan kurikulum, kegiatan pembelajaran yang mendidik, pengembangan potensi peserta didik, komunikasi dengan peserta didik, penilaian dan evaluasi. Variabel terikat dalam penelitian ini adalah motivasi belajar peserta didik meliputi keinginan untuk belajar, keterlibatan dalam pelaksanaan tugas belajar serta komitmen dan intensitas yang dimiliki individu untuk terus belajar. Populasi dalam penelitian ini adalah seluruh peserta didik di SMP IT Nidaul Hikmah Kota Salatiga yang berjumlah 167 peserta didik. Apabila jumlah populasinya lebih dari 100, maka yang menjadi sampel adalah 10\%-15\% atau 20\%-25\% atau lebih (Arikunto: 2016). Peneliti mengambil sampel 37\% dari populasi yang ada. Sampel dalam penelitian 
ini adalah peserta didik kelas VII B dan VIII B di SMP IT Nidaul Hikmah Kota Salatiga yang berjumlah 62 peserta didik dengan menggunakan teknik pengambilan sampel yaitu purposive sampling. Sampel bertujuan (purposive sampling) adalah teknik sampling yang digunakan oleh peneliti jika mempunyai pertimbangan-pertimbangan tertentu di dalam pengambilan sampelnya (Arikunto: 2016). Pertimbangannya berkaitan dengan penerapan pendidikan inklusi di kelas yaitu anak berkebutuhan khusus terdapat pada kelas VII B dan VIII B, sedangkan kelas IX B tidak dijadikan sebagai sampel dikarenakan sedang mempersiapkan ujian. Metode pengumpulan data dalam penelitian ini menggunakan angket. Instrumen angket telah diuji validitas dan reliabilitasnya. Teknik analisis data yang digunakan menggunakan uji hipotesis product moment dari Karel Pearson dengan aplikasi SPSS 25.0 for windows. Hipotesis dalam penelitian ini adalah adanya korelasi positif antara kompetensi pedagogik guru PAI dengan motivasi belajar peserta didik dalam Mata Pelajaran PAI pada sekolah inklusi di SMP IT Nidaul Hikmah Kota Salatiga Tahun Pelajaran $2018 / 2019$

\section{HASIL DAN PEMBAHASAN}

1. Data Persepsi Peserta Didik tentang Variasi Tingkat Kompetensi Pedagogik Guru PAI pada Sekolah Inklusi di SMP IT Nidaul Hikmah Kota Salatiga

Persepsi peserta didik tentang variasi tingkat kompetensi pedagogik guru diukur berdasarkan beberapa aspek yaitu pemahaman karakteristik peserta didik, pemahaman teori belajar dan prinsip-prinsip pembelajaran yang mendidik, kegiatan pembelajaran yang menarik, pengembangan potensi peserta didik dan komunikasi dengan peserta didik. Beberapa indikator dibuat menjadi 15 item dengan 11 item yang valid, setiap pernyataan memiliki 4 alternatif jawaban yang dapat dipilih oleh responden. Skoring setiap item diberikan penilaian dengan angka skor 1 sampai dengan 4 sesuai dengan jenis itemnya.

Tabel 1. Distribusi Frekuensi

Prosentase Persepsi Peserta Didik tentang Variasi Tingkat Kompetensi Pedagogik Guru PAI

\begin{tabular}{|c|c|c|c|c|}
\hline No. & Kategori & Interval & Frekuensi & Prosentase \\
\hline 1. & Sangat Rendah & $33-35$ & 2 & $3,2 \%$ \\
\hline 2. & Rendah & $36-38$ & 17 & $27,4 \%$ \\
\hline 3. & Sedang & $39-41$ & 30 & $48,4 \%$ \\
\hline 4. & Tinggi & $42-44$ & 13 & $20,9 \%$ \\
\hline & Jumlah & 62 & $100 \%$ \\
\hline
\end{tabular}

Berdasarkan perhitungan prosentase di atas dapat disimpulkan bahwa persepsi peserta didik tentang variasi tingkat kompetensi pedagogik guru PAI yang sangat rendah sebesar 3,2\%, 
rendah sebesar 27,9\%, sedang sebesar 48,4\% dan tinggi sebesar 20,9\%. Jadi menurut persepsi peserta didik, kompetensi pedagogik guru PAI di sekolah inklusi SMP IT Nidaul Hikmah Kota Salatiga tergolong dalam kategori sedang yaitu sebesar 48,4\%. Persepsi peserta didik tentang variasi tingkat kompetensi pedagogik Guru PAI di SMP IT Nidaul Hikmah tergolong sedang salah satu faktor penyebabnya adalah guru mempunyai peranan yang berbeda dalam mengatasi dan memahami peserta didik. Perbedaan karakteristik peserta didik menyebabkan guru di sekolah inklusi mempunyai kompetensi pedagogik yang berbeda dengan guru di sekolah reguler. Aspek-aspek kompetensi pedagogik guru melibatkan subjek peserta didik berkebutuhan khusus untuk memperoleh pelayanan yang sesuai dengan peserta didik pada umumnya. Terutama dalam mengarahkan peserta didik berkebutuhan khusus dalam konsep penerimaan diri yaitu menerima diri apa adanya, memiliki sikap positif atas dirinya, tidak terbebani oleh kecemasan atau rasa malu, dan mau menerima kelebihan dan kekurangan dirinya. Berdasarkan hal tersebut peserta didik dapat meningkatkan motivasi belajarnya. Peserta didik berkebutuhan khusus yang mengalamai gangguan tunadaksa dan slow learner dapat mengurangi aktifitas normal individu dalam mengikuti pendidikan. Penguasaan kompetensi pedagogik guru di sekolah inklusif sangat penting dalam dunia pendidikan sehingga perlu ditingkatkan melalui berbagai kegiatan yang mendukung.

2. Data Variasi Tingkat Motivasi Belajar Peserta Didik dalam Mata Pelajaran PAI pada Sekolah Inklusi di SMP IT Nidaul Hikmah Kota Salatiga

Motivasi belajar peserta didik dalam Mata Pelajaran PAI diukur berdasarkan beberapa aspek yaitu keinginan untuk belajar, keterlibatan dalam pelaksanaan tugas belajar dan komitmen intensitas yang dimiliki individu untuk terus belajar. Beberapa indikator dibuat menjadi 9 item dengan 8 item yang valid, setiap pernyataan memiliki 4 alternatif jawaban yang dapat dipilih oleh responden. Skoring setiap item diberikan penilaian dengan angka skor 1 sampai dengan 4 sesuai dengan jenis itemnya.

Tabel 2. Distribusi Frekuensi

Prosentase Variasi Tingkat Motivasi Belajar Peserta Didik dalam Mata PelajaranPAI

\begin{tabular}{|c|c|c|c|c|}
\hline No. & Kategori & Interval & Frekuensi & Prosentase \\
\hline 1. & Sangat Rendah & $24-25$ & 17 & $27,4 \%$ \\
\hline 2. & Rendah & $26-27$ & 17 & $27,4 \%$ \\
\hline 3. & Sedang & $28-29$ & 21 & $33,9 \%$ \\
\hline 4. & Tinggi & $30-31$ & 7 & $11,3 \%$ \\
\hline & Jumlah & 62 & $100 \%$ \\
\hline
\end{tabular}


Berdasarkan perhitungan prosentase tersebut dapat disimpulkan bahwa variasi tingkat motivasi belajar peserta didik dalam mata pelajaran PAI yang sangat rendah sebesar $27,4 \%$, rendah sebesar 27,4\%, sedang sebesar 33,9\% dan tinggi sebesar 11,3\%. Jadi motivasi belajar peserta didik dalam mata pelajaran PAI pada sekolah inklusi di SMP IT Nidaul Hikmah Kota Salatiga tergolong dalam kategori sedang yaitu sebesar 33,9\%. Motivasi belajar peserta didik pada mata pelajaran PAI termasuk dalam kategori sedang, dapat disebabkan oleh faktor eksternal berupa motivasi ekstrinsik yang diberikan. Motivasi ekstrinsik meliputi peran guru dan lingkungan. Penguasaan guru terhadap karakteristik peserta didik mempunyai hubungan dalam motivasi peserta didik. Guru yang mampu memberikan motivasi belajar kepada peserta didik mempunyai penguasaan kompetensi yang dimilikinya. Kompetensi guru dalam kategori sedang menyebabkan salah satu motivasi peserta didik dalam kategori sedang. Faktor penyebab lainnya adalah kondisi peserta didik yang heterogen dalam kelas. Terdiri dari peserta didik reguler dan berkebutuhan khusus. Peserta didik berkebutuhan khusus tunadaksa dan slow learner harus diberikan penguatan positif dan berbagai cara untuk memotivasi belajar yang lebih dibandingkan peserta didik reguler. Motivasi belajar peserta didik di SMP IT Nidaul Hikmah Kota Salatiga perlu ditingkatkan melalui berbagai aspek profesionalisme guru dan motivasi intrinsik dari peserta didik.

3. Analisis Uji Hipotesis

Penelitian ini menggunakan uji hipotesis analisis korelasi product moment. Uji korelasi untuk menguji hubungan antara variabel terikat dan variabel bebas yaitu antara kompetensi pedagogik guru PAI (X) dan motivasi belajar peserta didik pada mata pelajaran PAI (Y). Hasil dari analisis korelasi sebagai berikut:

Tabel 3. Hasil Uji Hipotesis Korelasi Product Momen

\begin{tabular}{|c|c|c|c|}
\hline \multirow{3}{*}{$\begin{array}{l}\text { Kompetensi } \\
\text { Pedagogik } \\
\text { Guru PAI }\end{array}$} & $\begin{array}{c}\text { Pearson } \\
\text { Correlation }\end{array}$ & 1 & $.495^{* *}$ \\
\hline & Sig. (2-tailed) & & .000 \\
\hline & $\mathrm{N}$ & 62 & 62 \\
\hline $\begin{array}{l}\text { Motivasi } \\
\text { Belajar Peserta } \\
\text { Didik Pada } \\
\text { Mata Pelajaran } \\
\text { PAI }\end{array}$ & $\begin{array}{l}\text { Pearson } \\
\text { Correlation }\end{array}$ & $.495^{* *}$ & 1 \\
\hline
\end{tabular}


Berdasarkan tabel di atas hipotesis nol (Ho) ditolak dan hipotesis alternatif (Ha) diterima dengan nilai $r_{x y}>r$ tabel sebesar 0,495 $>0,244$. Menunjukan bahwa hubungan kompetensi pedagogik guru PAI dengan motivasi belajar peserta didik dalam mata pelajaran PAI mempunyai korelasi positif yang sedang dan signifikan. Angka korelasi positif menunjukan hubungan yang positif, yaitu jika kompetensi pedagogik guru PAI meningkat maka motivasi belajar peserta didik pada mata pelajaran PAI juga meningkat. Nilai signifikansi yang didapat adalah 0,000 lebih kecil dari nilai signifikansi 0,05 maka terjadi hubungan yang signifikan. Hasil $r$ hitung $>r$ tabel yang diperoleh yaitu 0,495 $>0,244$ yang berada pada rentang $\geq 0,40-<0,70$. Menunjukan bahwa variabel $\mathrm{X}$ dan variabel $\mathrm{Y}$ terdapat hubungan positif yang sedang atau cukup. Berdasarkan data tersebut dapat diambil kesimpulan bahwa hubungan persepsi peserta didik tentang kompetensi pedagogik guru PAI dengan motivasi belajar dalam mata pelajaran PAI mempunyai korelasi positif yang sedang dan signifikan.

Kompetensi pedagogik guru PAI sangat penting dalam sekolah inklusi. Berfungsi untuk mengembangkan tujuan pembelajaran, desain kurikulum dan materi pembelajaran yang ada untuk peserta didik reguler dan berkebutuhan khusus. Motivasi peserta didik di sekolah inklusi berasal dari faktor internal dan eksternal. Faktor internal berasal dari dalam diri peserta didik sedangkan eksternal berasal dari peran guru dan lingkungan. Anak berkebutuhan khusus dengan berbagai jenis gangguan yang dialami dan anak reguler mempunyai motivasi belajar yang sama untuk senantiasa mengoptimalkan potensi yang dimilikinya. Peserta didik berkebutuhan khusus tunadaksa dan slow learner harus ditingkatkan motivasi belajar melalui berbagai cara. Contohnya dapat melalui penguatan positif dalam bentuk reward dan pujian. Semakin tinggi kompentensi pedagogik guru maka semakin tinggi motivasi belajar peserta didiknya. Kompetensi pedagogik guru PAI dan motivasi belajar peserta didik dalam mata pelajaran PAI pada sekolah inklusi di SMP IT Nidaul Hikmah Kota Salatiga perlu ditingkatkan.

\section{PENUTUP}

\section{Simpulan}

Persepsi peserta didik tentang variasi tingkat kompetensi pedagogik Guru PAI pada sekolah inklusi di SMP IT Nidaul Hikmah Kota Salatiga tahun pelajaran 2018/2019 tergolong sedang, salah satu faktor penyebabnya adalah guru mempunyai peranan yang berbeda dalam mengatasi dan memahami peserta didik. Motivasi belajar peserta didik dalam mata pelajaran PAI termasuk dalam kategori sedang hal ini dapat disebabkan oleh faktor eksternal berupa motivasi ekstrinsik yang diberikan. Terdapat korelasi positif dan signifikan antara persepsi peserta didik tentang kompetensi 
pedagogik guru PAI dengan motivasi belajar dalam mata pelajaran PAI pada Sekolah Inklusi di SMP IT Nidaul Hikmah Kota Salatiga dengan perhitungan korelasi product moment menghasilkan nilai $r_{x y}>r$ tabel sebesar 0,495 >0,244 dengan interprestasi cukup kuat dengan nilai signifikansi sebesar 0,000 dimana $0,000<0,05$.

\section{Saran}

Bagi peneliti selanjutnya yang berminat melakukan penelitian yang sama disarankan untuk mempertimbangkan teori yang dipakai sebagai alat ukur kompetensi guru yang lain dan mempertimbangkan lingkup basis sekolah yang akan diteliti.

\section{DAFTAR PUSTAKA}

Al-Zyoudi, Mohammed. 2006. Teachers' Attitudes Towards Inclusive Education In Jordanian Schools. International Journal Of Special Education. Vol. 21, No. 1

Arikunto Suharsimi. 2016. Manajemen Penelitian. Jakarta: Rineka Cipta

Ariastuti, Reni dan Vitri Dyah Herawati. 2016. Optimalisasi Peran Sekolah Inklusi. Jurnal Pengabdian Pada Masyarakat. Vol. 1, No. 1

Armstrong, Derrick, Dkk. 2011. Inclusion: By Choice Or By Chance?. International Journal Of Inclusive Education. Vol. 15, No. 1

Desiningrum, Dinie Ratri. 2016. Psikologi Anak Berkebutuhan Khusus. Yogyakarta: Psikosain.

Garnida, Dadang. 2015. Pengantar Pendidikan Inklusif. Bandung: Refika Ditama

Husein, Latifah. 2017. Profesi Keguruan Menjadi Guru Profesional. Yogyakarta: Pustaka Baru Press

Ilahi, Takdir Muhammad. 2013. Pendidikan Inklusif. Yogyakarta: Ar-Ruzz Media

Indrawan, Rully dan Poppy Yaniawati. 2016. Metodologi Penelitian. Bandung: PT. Refika Aditama.

Irwantoro Nur dan Yusuf Suryana. 2016. Kompetensi Pedagogik. Surabaya: Genta Goup Production.Use the "Insert Citation" button to add citations to this document.

Ismail. 2015. Peningkatan Kompetensi Pedagogik Guru PAI dalam Pembelajaran. Jurnal Mudarrisuna. Vol. 4, No. 2

Jung, Carl G., diterjemahkan oleh Afthonul Afif. 2017. Psikologi dan Agama. Yogyakarta: IRCiSoD

Lunenburg, Fred C. 2011. Goal-Setting Theory of Motivation. International Journal of Management, Business, and Administration. Vol. 15, No. 1 
Mahabbati, Aini. 2012. Pendidikan yang Inklusif dan Menyenangkan. Hasil Penelitian Disajikan dalam Seminar Nasional Diseminasi Hasil Pelatihan Luar Negeri Bidang Pendidikan Dasar Program Bermutu Dikti Hotel Grand Dafam MM Yogyakarta, 23-25 Mei.

Nuryovil, dkk. 2017. Persepsi Siswa tentang Kompetensi Pedagogik dan Kompetensi Kepribadian Guru. Journal of Mechanical Engineering Education. Vol. 4, No. 2

Santika, Dewa Ayu Putu Candra, dkk. 2013. Hubungan Antara Kompetensi Pedagogik dan Profesional Guru PPL Jurusan Pendidikan Teknik Informatika terhadap Motivasi Belajar Siswa SMK Se-Kota Singaraja. Jurnal Nasional Pendidikan Teknik Informatika. Vol. 6, No. 3

Sardiman, 2010. Interaksi dan Motivasi Belajar Mengajar. Jakarta: Raja Grafindo Persada

Siberman, Melvin L., diterjemahkan oleh Raisul Muttaqien. 2016. Active Learning. Bandung: Nuansa

Soetjipto dan Raflis Kosasi. 2009. Profesi Keguruan. Jakarta: Rineka Cipta.

Tarsidi, Didi. 2012. Disabilitas dan Pendidikan Inklusif pada Jenjang Pendidikan Tinggi. Jurnal Universitas Pendidikan Indonesia. Vol. 11. No. 2

Ulva, Maria dan Rizki Amalia. 2020. Proses Pembelajaran Matematika pada Anak Berkebutuhan Khusus (Autisme) di Sekolah Inklusi. Journal On Teacher Education. Vol. 1, No. 2.

Uno, Hamzah B. 2011. Teori Motivasi Dan Pengukurannya. Jakarta: Bumi Aksara

Vani, Gabriela Christina, dkk. 2013. Pengasuhan (Good Parenting) bagi Anak dengan Disabilitas. Prosiding KSM: Riset \& PKM. Vol. 2, No. 1

Wathoni, Kharisul. 2013. Implementasi Pendidikan Inklusi Dalam Pendidikan Islam. Jurnal Stain Ponorogo.Vol 1 No. 1

Wahyuningsih, Roy. 2017. Pengaruh Kompetensi Pedagogik dan Kompetensi Profesional Guru Terhadap Motivasi Belajar Siswa pada Mata Pelajaran Ekonomi di MAN 5 Jombang. Jurnal Pendidikan Ekonomi, Kewirausahaan, Bisnis, dan Manajemen.Vol. 1, No. 1 